\title{
PERANAN KELOMPOK TANI DALAM PENINGKATAN STATUS SOSIAL EKONOMI PETANI PADI SAWAH
}

\author{
Linys Elok Sari Wiranda ${ }^{1)}$, Sasmita Sari ${ }^{2 *}$ ) \\ Fakultas Pertanian, Universitas Abdurachman Saleh Situbondo \\ *Email Korespondensi : biantaka13@gmail.com
}

\begin{abstract}
Abstrak
Tujuan penelitian ini adalah untuk mengetahui perbedaan produksi dan pendapatan petani padi sawah antara sebelum dan sesudah menjadi anggota kelompok tani serta untuk mengetahui kendala yang dihadapi petani dalam menjalankan usaha padi sawah. Penentuan lokasi penelitian yang digunakan adalah purposive sampling yaitu daerah penelitian ditentukan secara sengaja dengan pertimbangan jumlah kelompok tani sangat mencukupi untuk pengambilan sampel dengan jumlah 30 responden. Data yang dikumpulkan terdiri dari data primer dan data sekunder yang diperoleh dari wawancara dan data dari instansi terkait. Metode analisis data yang digunakan adalah analisis uji t untuk mengetahui pengaruh kelompok tani terhadap pendapatan usaha tani padi sawah. Hasil penelitian menunjukkan ada perbedaan antara produksi petani sebelum menjadi anggota kelompok tani dengan sesudah menjadi anggota kelompok tani. Dimana produksi petani padi sawah sebelum menjadi anggota kelompok tani lebih rendah disbanding produksi petani padi sawah sesudah menjadi anggota kelompok tani. Terdapat perbedaan nyata antara pendapatan petani sebelum menjadi anggota kelompok tani dengan sesudah menjadi anggota kelompok tani. Pendapatan petani sebelum menjadi anggota kelompok tani lebih rendah dibandingkan sesudah menjadi anggota kelompok tani.
\end{abstract}

Kata Kunci : Kelompok Tani, Produksi, Pendapatan

\begin{abstract}
The purpose of the study is to determine differences in the production and income of rice farmers before and after becoming members of a farmer group as well as to determine the constraints faced by farmers in the operations of rice farming business. The research location was chosen by using purposive sampling, which the study area determined deliberately by considering the sufficient number of farmer groups for sampling, which is 30 respondents. The data collected consisted of primary data and secondary data obtained through interviews and data from relevant agencies. Data analysis methods used were $t$-test analysis to determine the effect of farmer groups on the income of rice farming business. The result shows that there are differences of rice production before and after the farmers becoming members of a farmer group. The rice production before becoming members of a farmer group is lower than the rice production after becoming members of a farmer group. Moreover, there is a real difference between the income of farmers before becoming members of a farmer group and the one after becoming members of a farmer group. Income of farmers before becoming members of a farmer group was lower than after becoming members of a farmer group.
\end{abstract}

Key Words: Farmer Group, Economy, Rice Farmers 


\section{PENDAHULUAN}

Pembangunan sering kali diartikan dengan pada oertumbuhan dan perkembangan. Pembangunan pertanian tidak terlepas dari peran serta masyarakat tani. Dengan peran yang sangat penting sebagai roda perekonomian negara, maka perlu dilakukan pemberdayaan masyarakat tani, sehingga petani mampu mandiri menyelesaikan masalah yang dihadapinya. Salah satu usaha pemerintah bersama petani dalam rangka membangun upaya kemandiriannya adalah dengan membentuk kelompok-kelompok tani di pedesaan. Kelompok tani menghendaki terwujudnya pertanian yang baik, usaha yang optimal, pendapatan yang meningkat dan keluarga tani yang sejahtera dalam perkembangan kehidupannya (Nainggolan dkk, 2014).

Peran sektor pertanian yang merupakan dasar bagi kelangsungan pembangunan ekonomi yang berkelanjutan diharapkan mampu memberikan pemecahan permasalahan bagi bangsa Indonesia. Karena sektor pertanian mempunyai 4 fungsi yang sangat fundamental bagi pembangunan suatu bangsa yaitu :

1. Mencukupi pangan dalam negeri

2. Penyediaan lapangan kerja dan usaha

3. Penyediaan bahan baku untuk industri, dan

4. Sebagai penghasil devisa bagi Negara.

Kondisi sosial budaya petani merupakan masalah utama dalam fungsi sektor pertanian di dalam pembangunan nasional dan kemampuan sektor tersebut untuk bersaing pada abad yang akan datang. Berdasarkan data statistik yang ada, saat ini sekitar 75\% penduduk Indonesia yang tinggal di wilayah pedesaan. Lebih dari 54\% diantaranya menggantungkan hidup pada sektor pertanian, dengan pendapatan yang relatif rendah jika dibandingkan dengan penduduk yang tinggal di perkotaan. Perbedaan tersebut berkaitan erat dengan produktifitas para petani Indonesia, yang tidak dapat dilepaskan dari berbagai faktor antara lain luas lahan yang dimiliki, kebijakan pemerintah dalam hal pemberian insentif kepada petani dan sebagainya (Santoso S.2004).

Dari aspek sosial ekonomi, peluang eksternal yang mendukung upaya peningkatan produksi padi anatara lain peningkatan permintaan beras merupakan jaminan pasar bagi petani padi, sistem pemasaran beras yang stabil dan efisien sehingga persentase marjin pemasaran cukup kecil, dan subsidi sarana produksi (pupuk dan benih) sehingga dapat memperkecil biaya produksi. Ketiga faktor diatas merupakan peluang yang dapat dimanfaatkan guna meningkatkan keuntungan usaha tani padi dan meningkatkan daya saing usaha tani padi. Semua peluang ini dapat meningkatkan motivasi petani dalam menanam padi (Irawan, 2008)

Ide membuat suatu kelompok berasal dari kenyataan bahwa setiap individu tidak akan dapat memenuhi kebutuhan dan harapan seorang diri. Individu terutama dalam masyarakat modern, merasa kurang mampu, kurang tenaga, kurang waktu dan tidak berdaya bila harus memenuhi sendiri kebutuhan dasar atas makanan, naungan maupun keselamatan. Bekerja bersama dalam kelompok adalah lebih murah dari pada kunjungan individu. Penyuluh Pembangunan (PP) jelas terbatas yang berarti bekerjasama dengan kelompok adalah lebih rendah biayanya. Dengan demikian kelompok dapat dikatakan sebagai kumpulan dari individu-individu yang memiliki pola perilaku dan saling berhubungan serta berinteraksi, sehingga diantara mereka memiliki hubungan erat dan bahkan timbul adanya perasaan bersama (Daniel Matanari, 2002). 
Sejak dulu, diantara tanaman bahan makanan, padi merupakan tanaman utama para petani Indonesia. Padi dapat ditanam di lahan kering (up-land) maupun lahan basah atau bisa disebut sawah (wet-land). Sawah berperan dominan dalam produksi padi karena pada umumnya padi memang ditanam di lahan jenis ini. Peningkatan produksi padi bermula pada awal dan berlangsungnya Pelita I, terutama hingga tingkat swasembada. Usaha peningkatan produksi padi tersebut berkat usaha bimbingan teknis oleh pemerintah kepada para petani secara serius, juga didukung oleh perbaikan infrastruktur secara fisik (jalan desa dan irigasi) maupun prasarana ekonominya. Beras dianggap sebagai komoditi strategis yang dominan dalam ekonomi Indonesia karena beras merupakan makanan pokok sebagian besar rakyat Indonesia. Kebutuhan beras setiap tahun bertambah sesuai pertambahan jumlah penduduk yang terus meningkat dan juga karena kebutuhan per kapita meningkat. Meningkatnya kebutuhan per kapita disebabkan oleh beralihnya penduduk bukan pemakan beras menjadi pemakan beras sebagai makanan pokoknya (Adiratma Roekasah, 2004).

Dari latar belakang diatas maka identifikasi masalah dari penelitian ini adalah

1. Apakah ada perbedaan produksi dan pendapatan petani padi sawah antara sebelum dan sesudah menjadi anggota kelompok tani?

2. Kendala apa yang dihadapi petani dalam menjalankan usaha tani padi sawah?

Adapun tujuan penelitian ini adalah sebagai berikut :

1. Untuk mengetahui perbedaan produksi dan pendapatan petani padi sawah antara sebelum dan sesudah menjadi anggota kelompok tani.

2. Untuk mengetahui kendala yang dihadapi petani dalam menjalankan usaha tani padi sawah.

\section{METODE PENELITIAN}

Daerah penelitian ditentukan secara purposive sampling. Penentuan daerah penelitian secara sengaja atau purposive sampling termasuk dalam sampling peluang (probability sampling), dimana dalam proses pemilihan sampel tidak melibatkan unsur-unsur peluang. Daerah yang dipilih menjadi tempat penelitian adalah Desa Klatakan, Kecamatan Kendit, Kabupaten Situbondo. Proses penelitian ini dilaksanakan setelah proposal ini disetujui yang rencananya sejak bulan Mei 2018 sampai bulan Agustus 2018.

Pengambilan sampel digunakan dengan mempergunakan metode probability. Dimana probability sampling adalah teknik yang memberi peluang/kesempatan yang sama bagi setiap unsur (anggota) populasi untuk dipilih menjadi anggota sampel. Pola tanam di Desa Klatakan yaitu padi sepanjang tahun, karena tersedianya air di musim kemarau. Kemudian letak geografisnya yang strategis karena berdekatan dengan kota Situbondo sehingga mempunyai akses yang lancar.

Teknik pengumpulan data menggunakan proportionate stratified random sampling. Dimana proportionate stratified random sampling bisa digunakan pada populasi yang mempunyai susunan bertingkat atau berlapis-lapis (Margono, 2004). Teknik ini digunakan bila populasi mempunyai anggota/unsur yang tidak homogen. Dan berstarata secara proporsional (sugiyono, 2001). Adapun pembagian sampel dari kelompok tani tersebut menurut luas lahan dengan menggunakan rumus Prasetyo dan Jannah (2005) yaitu : 


$$
\mathrm{NS}=\frac{P S}{\Sigma p} \times \text { Total }
$$

Diketahui :

NS = jumlah sampel pada strata

PS = Populasi sampel

$\Sigma \mathrm{p}=$ jumlah Populasi

Data yang diperlukan dalam penelitian ini adalah data primer dan data sekunder. Data primer diperoleh dengan cara observasi dan wawancara langsung dengan responden dengan menggunakan daftar pertanyaan yang telah disusun sesuai dengan tujuan penelitian. Data sekunder diperlukan untuk menunjang data primer yang diperoleh dari studi kepustakaan, dan instansi-instansi terkait dengan penelitian ini.

Untuk mengetahui pendapatan petani padi maka dianalisa penerimaan petani dikurangi biaya. Oleh karena itu, setiap kali melakukan analisis perlu disebutkan analisis apa saja yang digunakan (Soekartawi, 2006).

$$
\mathrm{TR}=\mathrm{Q} . \mathrm{P}
$$

Dimana :

$\begin{array}{ll}\text { TR } & =\text { Total Penerimaan } \\ \mathrm{Q} & =\text { Jumlah Produksi } \\ \mathrm{P} & =\text { Harga Produk }\end{array}$

$$
\mathrm{TC}=\mathrm{TFC}+\mathrm{TVC}
$$

Dimana :

$\mathrm{TC}=$ Total Biaya Produksi

$\mathrm{TFC}=$ Total Biaya Tetap

TVC $=$ Total Biaya Variabel

Sehingga pendapatan petani $\mathrm{P}(\mathrm{Y})=\mathrm{TR}-\mathrm{TC}$

Selain itu untuk tujuan penelitian 1 dan 2 menganalisis perbedaan produksi dan pendapatan petani digunakan uji statistik t-hitung untuk kelompok yang berpasangan (paired t sample), metode ini merupakan pengujian hipotesis dimana data yang digunakan tidak bebas (berpasangan). Ciri-ciri yang paling sering ditemui pada kasus yang berpasangan adalah satu individu (objek penelitian) dikenai 2 buah perlakuan yang berbeda. Walaupun menggunakan individu yang sama, penelitian tetap memperoleh 2 macam data sampel, yaitu data dari perlakuan pertama dan data dari perlakuan kedua, jika sampel 30 orang maka digunakan uji t (Singgih Santoso, 2006) dengan rumus sebagai berikut :

$$
\mathrm{t}=\frac{D}{S D / \sqrt{ } N}
$$

dimana :

$\mathrm{D} \quad=$ rata-rata selisih sebelum dan sesudah menjadi anggota kelompok tani

SD = standar devisiasi selisih sebelum dan sesudah menjadi anggota kelompok $\operatorname{tani}$

$\mathrm{N}=$ jumlah sampel 
Kriteria uji :

$\mathrm{t}$ - hit $\leq \mathrm{t}$-tabel hipotesis diterima

$\mathrm{t}$ - hit $\geq \mathrm{t}$-tabel hipotesis ditolak

untuk memudahkan penghitungan uji t dilakukan menggunakan aplikasi spss 23 .

\section{HASIL DAN PEMBAHASAN}

Peranan Kelompok Tani

Kelompok Pemuda Tani Jembatan Merah Klatakan belum mampu menguasai manejemen perencanaan dengan baik karena apa yang direncanakan tidak sesuai yang diharapkan terutama dalam hal perekonomian. Sedangkan untuk program kerja, Kelompokl Pemuda Tani Jembatan Merah Klatakan telah mampu melaksanakan kegiatan sesuai yang direncanakan. Selain itu, kelompok tani ini telah memiliki hubungan kerjasama dengan lembaga usaha lain salah satunya adalah koperasi. Anggota Kelompok Pemuda Tani Jembatan Merah Klatakan tidak mendapatkan bantuan dalam bentuk permodalan dari kelompok tani tersebut. Melainkan kerja sama dengan koperasi.

Penyuluh pertanian berperan penting dalam memberikan pengarahan kepada petani di Kelompok Pemuda Tani Jembatan Merah Klatakan yang dilakukan kurang lebih 2 kali pertemuan dalam sebulan. Anggota kelompok tani mendapatkan pengarahan khusus dari penyuluh karena setiap anggota kelompok mempunyai permasalahan yang berbeda dalam usaha tani mereka. Kelompok Pemuda Tani Jembatan Merah Klatakan mendapat bantuan subsidi dari pemerintah berupa benih dan pupuk. Kelompok tani ini telah menggunakan teknologi dalam usahataninya seperti mesin perontok. Keberadaan kelompok tani sangat dibutuhkan untuk membantu petani dalam melakukan budidaya sesuai SOP (Standart Operasional Procedure) sehingga hasil yang didapatkan sesuai dengan yang diharapkan.

Tabel 1. Rata-rata Produksi Sebelum dan Sesudah Menjadi Anggota Kelompok Tani

\begin{tabular}{cccc}
\hline No & Strata (Ha) & Sebelum $(\mathrm{Kg} / \mathrm{Ha})$ & Sesudah $(\mathrm{Kg} / \mathrm{Ha})$ \\
& & 2015 & 2018 \\
\hline 1. & $<0,5$ & 1.715 & $1.722,5$ \\
2. & $0,5-1,0$ & 3.850 & 4.325 \\
.3. & $>1,0$ & 6.050 & 7.500 \\
\hline & Rata-rata & $3.871,667$ & $4.515,833$ \\
\hline
\end{tabular}

Sumber : Data Primer, diolah 2018

Dari tabel 1 diketahui rata-rata produksi padi berdasarkan strata sebelum menjadi anggota kelompok tani 3.871,667 kg/ha, sementara setelah menjadi anggota kelompok rata-rata produksi padi mencapai $4.515,833 \mathrm{~kg} / \mathrm{ha}$. Produksi padi mengalami peningkatan setelah menjadi anggota kelompok tani dibandingkan dengan sebelum menjadi anggota kelompok tani.

\section{Pendapatan Petani Padi Anggota Kelompok Pemuda Tani Jembatan Merah Klatakan}

Pendapatan petani dari hasil produksi pengelolaan padi diperoleh dari hasil penerimaan penjualan padi dikurangi biaya total pengolahan usaha tani padi. Pada tabel berikut pendapatan petani antara sebelum dan sesudah menjadi anggota kelompok tani. 
Tabel 2. Rata-rata Pendapatan Petani Sebelum dan Sesudah Menjadi Anggota Kelompok Tani

\begin{tabular}{cccc}
\hline No & Strata $(\mathrm{Ha})$ & Sebelum $(\mathrm{Rp})$ & Sesudah $(\mathrm{Rp})$ \\
& & 2015 & 2018 \\
\hline 1. & $<0,5$ & 549.100 & 2.008 .325 \\
2. & $0,5-1,0$ & 3.694 .625 & 8.235 .000 \\
3. & $>1,0$ & 6.486 .500 & 16.913 .500 \\
\hline & Rata-Rata & 3.576 .750 & 9.052 .275
\end{tabular}

Sumber : Data Primer, diolah 2018

Sebelum menjadi anggota kelompok tani rata-rata pendapatan petani Rp 3.576.750, sementara setelah menjadi anggota kelompok tani rata-rata pendapatan meningkat menjadi Rp 9.052.275. Hal ini menunjukkan ada perbedaan pendapatan antara sebelum dan sesudah menjadi anggota kelompok tani.

\section{Uji Hipotesis}

Untuk mengetahui uji perbedaan pada hasil produksi padi dan pendapatan maka uji hipotesis menggunakan uji t sehingga dapat diketahui secara nyata perbedaan antara sebelum dan sesudah menjadi anggota kelompok tani.

\section{Uji T Produksi Padi Sebelum dan Sesudah Menjadi Kelompok Tani}

Uji hipotesis menunjukkan nilai $t=-5,772$ sedangkan $t$ tabel 1,697 artinya $t$ hitung lebih kecil t tabel sehingga terdapat perbedaan produksi padi yang signifikan antara sebelum dan sesudah menjadi anggota kelompok tani dengan taraf 95\%. H0 diterima dan H1 ditolak, hal tersebut juga terlihat pada rata-rata produksi pada tabel 18 rata-rata produksi sebelum menjadi anggota kelompok tani adalah 3.871,667 $\mathrm{kg} / \mathrm{ha}$ sedangkan rata-rata produksi sesudah menjadi anggota kelompok tani adalah 4.515,833 kg/ha. Sebelum dan sesudah menjadi anggota kelompok tani berbeda nyata.

\section{Uji T Pendapatan Padi Sebelum dan Sesudah Menjadi Kelompok Tani}

Uji hipotesis menunjukkan nilai t pada uji pendapatan petani antara sebelum dan sesudah menjadi anggota kelompok tani. $\mathrm{T}$ hitung $=-10,828$ sedangkan $\mathrm{t}$ tabel 1,697 artinya $t$ hitung lebih kecil dari t tabel sehingga pendapatan petani berbeda nyata antara sebelum dan sesudah menjadi anggota kelompok tani dengan taraf kepercayaan 95\%.

Pendapatan petani diperoleh dari usaha tani padi sawah. Besarnya pendapatan usahatani padi sawah dipengaruhi oleh produktifitas tanaman dan besarnya biaya yang dikeluarkan. Dapat disimpulkan terdapat perbedaan nyata antara pendapatan petani sebelum menjadi anggota kelompok dengan sesudah petani menjadi anggota kelompok tani. Pendapatan petani sebelum menjadi anggota kelompok tani lebih rendah dibandingkan sesudah menjadi anggota kelompok tani. Hal ini disebabkan produktifitas tanaman padi sawah petani sesudah menjadi anggota kelompok tani lebih tinggi dari pada sebelum menjadi anggota keolompok tani.

\section{Status Sosial Ekonomi}

Pada lampiran 16 untuk mengetahui status sosial dilihat dari luas lahan, pendidikan, dan pendapatan sebelum dan sesudah menjadi anggota kelompok tani. Sebagai sumber ekonomi terpenting bagi masyarakat desa khusunya petani, luas lahan dan kondisi sawah sebagai lahan pertanian sangat menentukan produksi dan pendapatan rumah tangga petani. Petani yang menguasai luas lahan sawah yang luas akan memperoleh hasil produksi yang besar dan begitu pula sebaliknya. Hasil tersebut menunjukkan luas lahan sebagian responden tergolong rendah. Luas lahan yang tertinggi yaitu 1,3 ha dengan petani bapak Sutikno. Dalam mengukur kondisi ekonomi seseorang atau rumah tanggga, salah satu konsep pokok yang paling sering digunakan yaitu melalui 
tingkat pendapatan-pendapatan. Pendapatan petani tergolong tinggi dan bisa dikatakan petani sebelum menjadi anggota kelompok tani pendapatan rendah sedangkan setelah menjadi anggota kelompok tani pendapatan tinggi. Dilihat dari pendapatan perekonomian petani meningkat yang mulanya sedang menjadi kaya. Pendidikan berperan penting dalam kehidupan manusia, pendidikan dapat bermanfaat seumur hidup manusia. Tingkat pendidikan orang tua bergerak dari tamat D3-sarjana, tamat SMA, tamat SMP dan tamat SD. Seseorang yang telah mendapatkan pendidikan diharapkan lebih baik. Namun dari hasil penelitian pendidikan formal petani tidak berpengaruh hal ini terlihat jelas pada jumlah pendapatan yang diterima petani. Kelompok tani berpengaruh terhadap perubahan pola budidaya petani sesuai SOP (Standart Operational procedure) sehingga petani mampu menghasilkan kualitas dan kuantitas hasil pertanian yang lebih baik.

\section{Kendala Usaha Tani Kelompok Pemuda Tani Jembatan Merah Klatakan} 1. Irigasi

Salah satu hal yang menjadi permasalahan petani anggota Kelompok Pemuda Tani "Jembatan Merah Klatakan" adalah masalah irigasi. Pada musim hujan sebagian besar lahan petani tergenang oleh air hujan. Tanah juga tidak dengan cepat meresap air serta saluran irigasi yang tidak mampu menampung aliran air hujan yang berakibat meluber ke lahan petani. Hal ini mengakibatkan tanaman menjadi rusak terlebih jika tanaman terendam berhari-hari. Sedangkan pada musim kemarau petani sulit mendapatkan air untuk tanaman mereka.

\section{Akses Transportasi}

Faktor Prasarana seperti jalan menuju lahan pertanian menjadi kendala dalam keberlangsungan produksi tanaman. Sebagian jalan masih terlihat berlubang dan bergelombang sehingga mengganggu petani dalam mengangkut hasil pertanian. Keadaan seperti ini menjadikan petani harus mengambil langkah alternatif dengan mengangkut hasil tanaman dengan cara manual menggunakan tenaga manusia hingga sampai di kendaraan yang akan mengangkut barang dijalan yang tidak rusak.

3. Hama

Hama menjadi masalah utama dalam bertani bagi petani anggota Kelompok Pemuda Tani "Jembatan Merah Klatakan". Hama yang menyerang adalah keong, tikus dan walang. Akibat hama ini petani mengalami kerugian akibat serangan hama keong, tikus dan walang. Mengendalikan pengendalian keong dengan cara manual yaitu mengambil keong satu persatu yang ada di sawah petani. Sementara untuk hama tikus dengan menggunakan racun tikus yang disebar dibeberapa sudut sawah. Dan untuk hama walang dengan menyemprotkan insektisida khusus walang.

\section{KESIMPULAN}

1. Ada perbedaan antara produksi padi sawah sebelum menjadi anggota kelompok tani dengan sesudah menjadi anggota kelompok tani. Dimana produksi padi sawah sebelum menjadi anggota kelompok tani lebih rendah dibanding produksi padi sawah sesudah menjadi anggota kelompok tani.

2. Terdapat perbedaan nyata antara pendapatan petani sebelum menjadi anggota kelompok tani dengan sesudah menjadi anggota kelompok tani. Pendapatan petani sebelum menjadi anggota kelompok tani lebih rendah dibandingkan sesudah menjadi anggota kelompok tani.

3. Kendala-kendala yang dihadapi kelompok tani dalam kegiatan usaha taninya adalah hama, saluran irigasi yang kurang baik dan transportasi yang tidak dapat dilalui oleh kendaraan. 


\section{REFERENSI}

Aristati dan Bambang. 2007. Analisis Faktor-Faktor yang Mempengaruhi Pendapatan Petani di Kabupaten Langkat. Tesis USU. Medan.

Bramantyo, Djohanputro. 2006. Prinsip-prinsip Ekonomi Makro. Jakarta : penerbit PPM.

Daniel Matanari. 2002. Metode Penelitian Sosial Ekonomi. Bumi Aksara Jakarta.

Deptan, 2016. Peraturan Menteri Pertanian No.67/Permentan/Sm.050/12/2016 Tentang Pembinaan Kelembagaan Petani. Departemen Pertanian. Jakarta.

Elvera Roza, 2005. Peranan Kelompok Tani Dalam Peningkatan Sosial Ekonomi Petani Sayur Mayur Di Kel. Tanah Enam Ratus Kec. Medan Marelan Kota Medan, Fakultas Pertanian USU. Medan.

Gustiyana, 2004. Ilmu Usahatani, Penerbit Penebar Swadaya Jakarta.

Irawan. B. 2003. Konversi Lahan Sawah di Jawa dan Dampaknya terhadap Produksi Padi (Land Conversion in Java and its Impact on Rice Production) in Kasryno et al. (Eds). Ekonomi Padi dan Beras Indonesia (Indonesian Rice Economy). Indonesian Agency For Agricultural Research and Development, Jakarta. 